\title{
Brewing microbiology - bacteria of the genera Bacillus, Brevibacillus and Paenibacillus and cultivation methods for their detection - part 2 Mikrobiologie pivovarské výroby - bakterie rodů Bacillus, Brevibacillus a Paenibacillus a kultivační metody pro jejich detekci - 2. část
}

\author{
Martina BROŽOVÁ, Petra KUBIZNIAKOVÁ, Dagmar MATOULKOVÁ \\ Department of Microbiology, Research Institute of Brewing and Malting, Lípová 15, CZ 12044 Prague \\ Mikrobiologické oddělení, Výzkumný ústav pivovarský a sladařský, a.s., Lípová 15, 12044 Praha 2
}

e-mail:brozova@beerresearch.cz,kubizniakova@beerresearch.cz, matoulkova@beerresearch.cz

Reviewed paper / Recenzovaný článek

\begin{abstract}
Brožová, M., Kubizniaková, P., Matoulková, D., 2018: Brewing microbiology- bacteria of the genera Bacillus, Brevibacillus and Paenibacillus and cultivation methods for their detection - part 2. Kvasny Prum. 64(5): 233-241

This publication is a sequel to the study Microbiology of brewing - bacteria of the genera Bacillus, Brevibacillus and Paenibacillus and cultivation methods for their detection - part 1 (Brožová et al.: Kvasny Prum., 64(2): 50-57, 2018). We monitored the growth of 5 brewery significant strains of the genera Bacillus, Brevibacillus and Paenibacillus on solidified culture media. The publication contains photographic documentation of bacterial colonies and the use of culture media in the laboratory of brewing operations is discussed.
\end{abstract}

Brožová, M., Kubizniaková, P., Matoulková, D., 2018: Mikrobiologie pivovarské výroby - bakterie rodů Bacillus, Brevibacillus a Paenibacillus a kultivační metody pro jejich detekci - 2. část. Kvasny Prum. 64(5): 233-241

Publikace je pokračováním rešeršního článku Mikrobiologie pivovarské výroby - bakterie rodů Bacillus, Brevibacillus a Paenibacillus a kultivační metody pro jejich detekci - část I (Brožová et al.: Kvasny Prum., 64(2): 50-57, 2018). Sledován byl růst 5 pivovarsky významných kmenů bakterií rodů Bacillus, Brevibacillus a Paenibacillus na vybraných ztužených kultivačních půdách. $V$ publikaci je obsažena fotodokumentace bakteriálních kolonií a diskutována je využitelnost kultivačních médií v provozní pivovarské laboratoři.

Keywords: aerobic bacteria, facultative anaerobic bacteria, Bacillus, Bacillus cereus, Bacillus licheniformis, Brevibacillus, Paenibacillus, spores

\section{INTRODUCTION}

Bacteria of the genus Bacillus are considered to be a low-risk contaminants of beer. They are not able to grow in beer and therefore do not affect its biological stability (Back, 2005; Basařová et al., 2010; Vaughan et al., 2005). Spores, resting forms, are extremely resistant to environmental conditions. Therefore, the spores created by these bacteria may survive even for a long time in the distributed beer and germinate under suitable conditions (especially in less hopped beers and beers with higher $\mathrm{pH}$ ). Haakensen and Ziola (2008) confirmed the ability of the strains $B$. cereus $\mathrm{MH} 1$ and $B$. licheniformis $\mathrm{MH} 2$ to grow even after inoculation into finished beer incubated at $30{ }^{\circ} \mathrm{C}$. B. cereus may represent an increased risk due to its ability to produce various toxins (Logan and De Vos, 2015a). Undesirable is also the ability of some bacilli to reduce nitrates to nitrites that may cause the formation of $\mathrm{N}$-nitrosamines in beer (Back, 2005; Bokulich and Bamforth, 2013; Briggs et al., 2004). Strains Brevibacillus brevis and Paenibacillus macerans are widespread in the environment on the solid plant materials and they can easily get into the breweries with raw materials (Back, 2005; Priest, 2015).

This study deals with the most commonly used media for the cultivation and detection of bacteria $B$. cereus, $B$. licheniformis, Bacillus subtilis, $B$. brevis and $P$. macerans. Commercially available diagnostic media used for the identification of $B$. cereus are also included in this study. We selected a group of 5 strains of the genera Bacillus, Brevibacillus and Paenibacillus, which were detected in the brewing operations. The strains were chosen based on their availability in the collections of microorganisms. We tested 6 different commercially available agar media designed for cultivation and diagnostics of the above-mentioned bacterial species. Furthermore, cultivation was conducted on culture media used for the detection of coliform bacteria in the brewing operations - Chromocult Coliform agar, Endo agar and MacConkey agar and for the detection of lactic acid bacteria MRS agar. The aim of the study was to assess the growth rate of selected strains on the particular culture media, the morphology of colonies and provide photographic documentation.
Klíčová slova: aerobní bakterie, fakultativně anaerobní bakterie, Bacillus, Bacillus cereus, Bacillus licheniformis, Brevibacillus, Paenibacillus, spory

\section{1 ÚVOD}

Rod Bacillus je považován za málo rizikovou kontaminantu piva. Není schopen rưstu v pivu a neovlivňuje tedy jeho biologickou stabilitu (Back, 2005; Basařová et al., 2010; Vaughan et al., 2005). Spory, klidové formy, extrémně odolné k podmínkám prostředí, vytvářené těmito bakteriemi však mohou v distribuovaném pivu přežít i po dlouhou dobu a za vhodných podmínek (zejména u méně chmelených piv a u piv s vyššími hodnotami pH) vykličit. V práci Haakensen a Ziola (2008) byla potvrzena schopnost kmenů Bacillus cereus $\mathrm{MH1}$ a Bacillus licheniformis $\mathrm{MH} 2$ růst i po naočkování do hotového piva, které bylo inkubováno při teplotě $30^{\circ} \mathrm{C}$. Díky své schopnosti produkovat celou řadu toxinů, by tak mohl $B$. cereus představovat zvýšené riziko (Logan a De Vos, 2015a). Nežádoucí je i schopnost některých bacilů redukovat dusičnany na dusitany, které mohou být prríčinou vzniku N-nitrosaminů v pivu (Back, 2005; Bokulich a Bamforth, 2013; Briggs et al., 2004). Druhy Brevibacillus brevis a Paenibacillus macerans jsou hojně rozšířeny v životním prostředí na pevných rostlinných materiálech a mohou se snadno dostávat do pivovarských provozů se vstupními surovinami (Back, 2005; Priest, 2015).

Tato studie se zabývá nejčastěji používanými půdami pro kultivaci a detekci bakterií B. cereus, B. licheniformis, Bacillus subtilis, Brevibacillus brevis a $P$. macerans. Do studie byla zahrnuta komerčně dostupná diagnostická média používaná pro stanovení $B$. cereus. Byla vybrána skupina 5 kmenů bakterií rodů Bacillus, Brevibacillus a Paenibacillus, které byly detekovány v pivovarských provozech. Při výběru kmenů bylo přihlédnuto $k$ jejich dostupnosti ve sbírkách mikroorganismů. Testovali jsme 6 různých komerčně dostupných agarových médií, určených pro kultivaci a diagnostiku výše uvedených bakteriálních druhư. Dále byly kultivace vedeny na pưdách používaných $v$ pivovarských provozech pro stanovení koliformních bakterií - Chromocult Coliform agar, Endův agar a MacConkeyho agar a k detekci mléčných bakterií - MSR agar. Cílem práce bylo posouzení rychlosti růstu vybraných kmenů na jednotlivých kultivačních půdách, fotodokumentace a popis morfologie kolonií. 


\section{CULTIVATION AND DETECTION OF SELECTED TAXONS}

For the determination of the number of spore forming bacteria, the vegetative forms of spore forming and other microorganisms have to be inactivated with heat prior to cultivation. The aim of this step is to kill the vegetative bacilli cells and cells of non-spore forming microorganisms and also activate the germination of the spores. Thermal inactivation of the sample should take place within 10 minutes of preparation of the first sample dilution. The temperature of the dilution samples should be as low as possible, to avoid underestimation of the number of spores due to their germination during the preparation of samples and subsequent killing by the thermal inactivation (Te Giffel et al., 1995).

Bacillus cereus - grows on common enriched media (e.g. blood agar or $\mathrm{BHI}=$ brain heart infusion agar), on which it creates large, light creamy and opaque colonies with irregular edges and a dry wrinkled surface (Drobniewski, 1993; Logan and De Vos, 2015; Salkinoja-Salonen et al., 1999). The diagnostics of $B$. cereus makes use of culture media which contain selective components (polymyxin B) inhibiting the growth of the associated microorganisms. When using selective diagnostic culture media, egg yolk and mannitol are usually included into these media. Mannitol-egg yolk polymyxin agar (MYP) is intended for the isolation of $B$. cereus from food according to CSN EN ISO 7932 (2005). The diagnostic components in these media are egg yolk (precipitation due to the lecithin hydrolysis) and mannitol. Unlike the other species of genus Bacillus, $B$. cereus is not able to utilize mannitol. Cultivation then takes $20-24$ hours at $30-32{ }^{\circ} \mathrm{C}$. Bacillus cereus creates large flat colonies $2-5 \mathrm{~mm}$ in diameter with irregular edges, which have a dry and rough surface. Colonies are creamish-pink (mannitol is not metabolised) with a pink zone of precipitation (lecithinase activity) (Kramer and Gilbert, 1989). Other commonly used selective-diagnostic media are polymyxin-pyruvate-egg yolk-mannitol agar with addition of bromothymol blue (PEMBA) or bromocresol red, Trypticase Soy Broth (TSB) with the addition of polymyxin $\mathrm{B}$, Bacillus cereus medium (BCM) or chromogenic media (detection based on $\beta$-glucosidase activity). During cultivation of $B$. cereus on PEMBA, it creates large turquoise colonies with irregular edges and a diameter of about $2-5 \mathrm{~mm}$ after 18-24 hours at $37^{\circ} \mathrm{C}$ (Kramer and Gilbert, 1989). MYP agar provides better identification of $B$. cereus and makes it easier to determine $B$. cereus because fewer confirmatory tests are needed (Drobniewski, 1993; Harmon et al., 1984). To determine the presence of the $B$. cereus spores, thermal inactivation is performed at $62.5^{\circ} \mathrm{C}$ for 15 minutes and its subsequent cultivation is performed on a suitable selective medium at $32-35^{\circ} \mathrm{C}$ (Drobniewski, 1993).

Bacillus licheniformis - grows on most common culture media (nutrient or blood agar) (Salkinoja-Salonen et al., 1999). The studies also mention $\mathrm{BHI}$ agar (brain heart infusion agar) (Cladera-Olivera et al., 2004). For the diagnostics of $B$. licheniformis are used the same culture media as for $B$. cereus, e.g. MYP, PEMBA or TSB (Němečková et al., 2011; Salkinoja-Salonen et al., 1999). On MYP and PEMBA agar, $B$. licheniformis forms medium-sized yellow to yellow-green colonies with irregular edges with a diameter up to $5 \mathrm{~mm}$ (Němečková et al., 2011). To determine the presence of the spores, thermal inactivation is performed at $80^{\circ} \mathrm{C}$ for 10 minutes. Then follows cultivation at $50{ }^{\circ} \mathrm{C}$ on nutrient agar enriched with $\mathrm{KNO}_{3}$, on which $B$. licheniformis forms creamy to reddish, mucoid colonies with undulate to lobate edges (Logan and De Vos, 2015).

Bacillus subtilis - grows on common culture media such as, e.g., blood agar, BHI agar, TSB agar or nutrient agar (Salkinoja-Salonen et al., 1999). Other culture media include Penassay broth with the addition of chloramphenicol or magnesium, Penassay G-TH (glucose-thiamine) medium (Atlas, 2010) or Luria-Bertani agar (LB agar), on which B. subtilis forms gray wrinkled colonies (Back, 2005). Selective media for $B$. subtilis are not published.

Brevibacillus brevis and Paenibacillus macerans - grow on common culture media such as nutrient agar or TSB (Logan and De Vos, 2015; Nehra et al., 2016; Priest, 2015). On these media, Brevibacillus brevis forms glossy, milky, cream-colored colonies $1-3 \mathrm{~mm}$ in diameter (Logan and De Vos, 2015). Tyrosine agar is recommended as a selective medium for the determination of $B$. brevis. Brevibacillus brevis utilizes tyrosine and forms colonies with a typical light brown pigment on this medium (Edwards and Seddon, 2000). Selective media for Paenibacillus macerans are not published.

\section{KULTIVACE A DETEKCE VYBRANÝCH TAXONU゚}

Pro stanovení počtu sporotvorných bakterií je před samotnou kultivací nutné tepelně inaktivovat vegetativní formy sporotvorných i ostatních mikroorganismů. Cílem tohoto kroku je usmrcení vegetativních buněk bacilů a nesporotvorných mikroorganismů a zároveň aktivace germinace (klíčení) spor. Tepelná inaktivace vzorku by měla proběhnout do 10 minut od prípravy prvního ředění vzorku a teplota ředících vzorků by měla být co nejnižší, aby nedocházelo k podhodnocení počtu spor $v$ důsledku jejich vyklíčení během př́pravy vzorku a následného usmrcení inaktivačním záhřevem (Te Giffel et al., 1995).

Bacillus cereus - roste na běžných obohacených médiích (např. krevní agar či $\mathrm{BHI}=$ brain heart infusion agar), na kterých vytváŕi velké světle krémové a neprůhledné kolonie s nepravidelnými okraji a suchým zvrásněným povrchem (Drobniewski, 1993; Logan a De Vos, 2015; Salkinoja-Salonen et al., 1999). Pro diagnostiku B. cereus se používají živná média obsahující selektivní složky (polymyxin $\mathrm{B}$ ) inhibující růst přidružených mikroorganismů. $\mathrm{V}$ případě použití selektivně diagnostických půd bývá součástí médií obvykle vaječný žloutek a manitol. Pro izolaci $B$. cereus z potravin je podle ČSN EN ISO 7932 (2005) určen Mannitol-egg yolk polymyxin agar (MYP). Jako diagnostická složka je $v$ této půdě využíván vaječný žloutek (precipitace $\mathrm{v}$ důsledku hydrolysy lecitinu) a manitol, který není $B$. cereus na rozdíl od jiných druhư rodu Bacillus schopen utilisovat. Kultivace probíhá $20-24$ hodin prí teplotě $30-32{ }^{\circ} \mathrm{C}$. Bacillus cereus tvoří velké nevypouklé kolonie $s$ nepravidelnými okraji o průměru 2-5 mm, které mají suchý a zdrsnělý povrch. Kolonie jsou krémově-rưžové (manitol není metabolisován), obklopené růžovou zónou precipitace (lecitinasová aktivita) (Kramer a Gilbert, 1989). Dalšími běžně používanými selektivně-diagnostickými půdami jsou polymyxin-pyruvate-egg yolk-mannitol agar $s$ prídavkem bromthymolové modři (PEMBA) nebo bromkresolové červeni, Trypticase Soy Broth (TSB) s prídavkem polymyxinu $\mathrm{B}$, Bacillus cereus médium (BCM) či chromogenní média (detekce na základě $\beta$-glukosidasové aktivity). Při kultivacích $B$. cereus za použití PEMBA se po 18-24 hodinách při $37^{\circ} \mathrm{C}$ vytvoři velké tyrkysové kolonie s nepravidelnými okraji o prùměru cca 2-5 mm (Kramer a Gilbert, 1989). MYP agar poskytuje lepší identifikaci $B$. cereus a jeho stanovení je snadnější, jelikož je následně potřeba méně potvrzovacích testů (Drobniewski, 1993; Harmon et al., 1984). Pro stanovení prítomnosti spor B. cereus se tepelná inaktivace provádí při $62,5^{\circ} \mathrm{C}$ po dobu 15 minut a následná kultivace je vedena na vhodném selektivním médiu prí teplotách $32-35^{\circ} \mathrm{C}$ (Drobniewski, 1993).

Bacillus licheniformis - roste na většině běžných kultivačních půd (masopeptonový či krevní agar) (Salkinoja-Salonen et al., 1999). Ve studiích je také zmiňován BHI agar (brain heart infusion agar) (Cladera-Olivera et al., 2004). Pro diagnostiku B. licheniformis jsou používána stejná živná média jako $v$ prípadě $B$. cereus, tedy např. MYP, PEMBA či TSB (Němečková et al., 2011; Salkinoja-Salonen et al., 1999). Na MYP a PEMBA agaru tvoří $B$. licheniformis středně velké žluté až žluto-zelené kolonie s nepravidelnými okraji o průměru do $5 \mathrm{~mm}$ (Němečková et al., 2011). Pro stanovení př́tomnosti spor se tepelná inaktivace provádí prí $80^{\circ} \mathrm{C}$ po dobu 10 minut. Poté následuje kultivace při $50^{\circ} \mathrm{C}$ na masopeptonovém agaru obohaceném o $\mathrm{KNO}_{3}$, kde $B$. licheniformis tvoří krémové až načervenalé slizovité kolonie s výčnělky a lalǔčky (Logan a De Vos, 2015).

Bacillus subtilis - roste na běžných médiích, jako je např. krevní agar, BHI agar, TSB agar či masopeptonový agar (Salkinoja-Salonen et al., 1999). V publikacích jsou také uváděny kultivační půdy Penassay bujón s prídavkem chloramfenikolu či hořčíku, Penassay G-TH (glucosa-thiamin) médium (Atlas, 2010) nebo Luria-Bertani agar (LB agar), na kterém tvoří $B$. subtilis šedavé zvrásnělé kolonie (Back, 2005). Selektivní půdy pro stanovení $B$. subtilis nejsou publikovány.

Brevibacillus brevis a Paenibacillus macerans - rostou na běžných médiích, jako např. masopeptonový agar či TSB (Logan a De Vos, 2015; Nehra et al., 2016; Priest, 2015). Brevibacillus brevis tvorí na těchto půdách lesklé, mléčné, krémově zbarvené kolonie o průměru 1-3 mm (Logan a De Vos, 2015). Jako selektivní médium pro stanovení Brevibacillus brevis je doporučován tyrosinový agar. $B$. brevis utilisuje tyrosin a vytvárí na této půdě kolonie s typickým světle hnědým pigmentem (Edwards a Seddon, 2000). Selektivní půdy pro stanovení Paenibacillus macerans nejsou publikovány. 


\section{MATERIALS AND METHODS}

\subsection{Composition and preparation of culture media}

a) PC agar (Plate Count agar) (PCA): was prepared from dehydrated medium according to manufacturer's instructions (Merck): by dissolving $22.5 \mathrm{~g}$ of dehydrated medium in $1000 \mathrm{ml}$ of distilled water and sterilizing it for 20 minutes at $121^{\circ} \mathrm{C}$. Finished medium has a light yellow color.

b) Meat-peptone agar (nutrient agar) (MPA): was prepared from dehydrated medium according to manufacturer's instructions (Merck): by dissolving $20 \mathrm{~g}$ of dehydrated medium in $1000 \mathrm{ml}$ of distilled water and sterilizing it for 20 minutes at $121^{\circ} \mathrm{C}$. Finished medium has a light yellow color.

c) Soyabean Casein Diges Medium (Tryptone Soya Broth) (TSB) with the addition of polymyxin B: was prepared from dehydrated medium according to manufacturer's instructions (HiMedia): by dissolving $30 \mathrm{~g}$ of dehydrated medium in $1000 \mathrm{ml}$ of distilled water with the addition of $15 \mathrm{~g}$ of bacteriological agar (Oxoid, $1.5 \%$ ) and sterilizing it for 20 minutes at $121^{\circ} \mathrm{C}$. Before pouring onto plates: to finished and cooled $\left(45-50^{\circ} \mathrm{C}\right)$ medium was aseptically added a rehydrated polymyxin B sulfate (HiMedia, 50000 USP) solution to a final concentration of 100 units per $\mathrm{ml}$. Finished medium has a light slightly yellowish color.

d) Blood agar (KA): was prepared from dehydrated medium according to manufacturer's instructions (Merck): by dissolving $40 \mathrm{~g}$ of dehydrated medium in $1000 \mathrm{ml}$ of distilled water and sterilizing it for 20 minutes at $121^{\circ} \mathrm{C}$. Before pouring onto plates: to finished and cooled $\left(45-50^{\circ} \mathrm{C}\right)$ medium was aseptically added defibrinated ram blood to a final concentration of $8 \%$. Finished medium has a dark reddish-brown color.

e) MYP agar (Phenol Red Egg Yolk Polymyxin Agar) (MYP): was prepared from dehydrated medium according to manufacturer's instructions (HiMedia): by dissolving $46.0 \mathrm{~g}$ of dehydrated medium in $900 \mathrm{ml}$ of distilled water and sterilizing it for 20 minutes at $121^{\circ} \mathrm{C}$. Before pouring onto plates: to finished and cooled $\left(45-50^{\circ} \mathrm{C}\right)$ medium was aseptically added $100 \mathrm{ml}$ egg yolk emulsion (HiMedia) and a rehydrated polymyxin B sulfate (HiMedia 50000 USP) solution to a final concentration of 100 units per ml. Finished medium has a light pinkish-orange color.

f) PEMB agar (Polymyxin Pyruvate Egg Yolk Mannitol Bromothymol Blue Agar) (PEMBA): was prepared from dehydrated medium according to manufacturer's instructions (HiMedia): by dissolving $46.4 \mathrm{~g}$ of dehydrated medium in $950 \mathrm{ml}$ of distilled water and sterilizing it for 20 minutes at $121^{\circ} \mathrm{C}$. Before pouring onto plates: to finished and cooled $\left(45-50{ }^{\circ} \mathrm{C}\right)$ medium was aseptically added $50 \mathrm{ml}$ egg yolk emulsion (HiMedia) and a rehydrated polymyxin $\mathrm{B}$ sulfate (HiMedia, 50000 USP) solution to a final concentration of 100 units per ml. Finished medium has a light bright green color.

g) Chromocult Coliform agar (Coli): was prepared from dehydrated medium according to the manufacturer's instructions (Merck) by dissolving $26.5 \mathrm{~g}$ of dehydrated medium in $1000 \mathrm{ml}$ of distilled water and sterilizing it for 20 minutes at $121^{\circ} \mathrm{C}$. Finished medium has a light slightly yellowish color.

h) Endo agar (Endo): was prepared from dehydrated medium according to the manufacturer's instructions (Merck): by dissolving $39 \mathrm{~g}$ of dehydrated medium in $1000 \mathrm{ml}$ of distilled water and sterilizing it for 20 minutes at $121^{\circ} \mathrm{C}$. Finished medium has a dark pink color.

i) MacConkey agar (Mac): was prepared from dehydrated medium according to the manufacturer's instructions (Merck): by dissolving $50 \mathrm{~g}$ of dehydrated medium in $1000 \mathrm{ml}$ of distilled water and sterilizing it for 20 minutes at $121^{\circ} \mathrm{C}$. Finished medium has a light pink color.

j) MRS agar (De Man, Rogosa and Sharpe agar) (MRS): was prepared from dehydrated medium according to manufacturer's instructions (Merck): by dissolving $68.2 \mathrm{~g}$ of dehydrated medium in $1000 \mathrm{ml}$ of distilled water and sterilizing it for 20 minutes at $121^{\circ} \mathrm{C}$ Before pouring onto plates: to finished and cooled $\left(45^{\circ} \mathrm{C}\right)$ medium was aseptically added actidione $(0.025 \mathrm{~g}$ of actidione in $10 \mathrm{ml}$ of distilled water) and $\beta$-phenylethanol at a final concentration of $0.3 \%$ vol. Finished medium has a yellowish-brown color.

\subsection{Microorganisms and culture conditions}

Strains of bacteria that were used in this study originate from the Czech Collection of Microorganisms (CCM) in Brno. The list of the strains and their designations are listed in Table 1. The strains were stored on oblique nutrient (MPA) agar under paraffin oil. Prior to inoculation to test media, the strains were incubated for $48 \mathrm{~h}$ on MPA agar at $28^{\circ} \mathrm{C}$.

\section{MATERIÁL A METODY}

\subsection{Složení a příprava kultivačních médi}

a) PC agar (Plate Count agar) (PCA): byl připraven z dehydratované pưdy dle návodu výrobce (Merck): rozpuštěním 22,5g dehydratované půdy v $1000 \mathrm{ml}$ destilované vody a sterilizací 20 minut při $121^{\circ} \mathrm{C}$. Hotová půda měla světle žlutou barvu.

b) Masopeptonový agar (nutrient agar) (MPA): byl připraven z dehydratované půdy dle návodu výrobce (Merck): rozpuštěním $20 \mathrm{~g}$ dehydratované půdy v $1000 \mathrm{ml}$ destilované vody a sterilizací 20 minut při $121^{\circ} \mathrm{C}$. Hotová půda měla světle žlutou barvu.

c) Soyabean Casein Diges Medium (Tryptone Soya Broth) (TSB) $s$ př́davkem polymyxinu $B$ : byl pripraven $z$ dehydratované půdy dle návodu výrobce (HiMedia): rozpuštěním $30 \mathrm{~g}$ dehydratované půdy v $1000 \mathrm{ml}$ destilované vody s prídavkem $15 \mathrm{~g}$ bakteriologického agaru (Oxoid, $1,5 \%$ ) a sterilací 20 minut prí $121^{\circ} \mathrm{C}$. Do hotové a ochlazené $\left(45-50^{\circ} \mathrm{C}\right)$ půdy byl před jejím nalitím na misky asepticky přidán rehydratovaný polymyxin B sulfát (HiMedia, 50000 m.j.) tak, aby bylo dosaženo konečné koncentrace 100 jednotek polymyxinu $B$ na $\mathrm{ml}$ média. Hotová půda měla světlou lehce nažloutlou barvu.

d) Krevní agar (Blood agar) (KA): byl připraven z dehydratované půdy dle návodu výrobce (Merck): rozpuštěním $40 \mathrm{~g}$ dehydratované půdy v $1000 \mathrm{ml}$ destilované vody a sterilizací 20 minut při 121 ${ }^{\circ} \mathrm{C}$. Do hotové a ochlazené $\left(45-50^{\circ} \mathrm{C}\right)$ půdy byla pred jejím nalitím na misky asepticky přidána defibrinovaná beraní krev tak, aby bylo dosaženo konečné koncentrace $8 \%$ beraní krve. Hotová půda měla tmavou červeno-hnědou barvu.

e) MYP agar (Phenol Red Egg Yolk Polymyxin Agar) (MYP): byl připraven $z$ dehydratované půdy dle návodu výrobce (HiMedia): rozpuštěním $46,0 \mathrm{~g}$ dehydratované půdy v $900 \mathrm{ml}$ destilované vody a sterilací 20 minut při $121^{\circ} \mathrm{C}$. Do hotové a ochlazené $\left(45-50^{\circ} \mathrm{C}\right)$ půdy bylo před jeiím nalitím na misky asepticky přidáno $100 \mathrm{ml}$ emulze vaječného žloutku (HiMedia) a rehydratovaný polymyxin B sulfát (HiMedia, 50000 m.j.) tak, aby bylo dosaženo konečné koncentrace 100 jednotek polymyxin B sulfátu na $1 \mathrm{ml}$ média. Hotová půda měla světlou rưžovo-oranžovou barvu.

f) PEMB agar (Polymyxin Pyruvate Egg Yolk Mannitol Bromothymol Blue Agar) (PEMBA): byl připraven z dehydratované půdy dle návodu výrobce (HiMedia): rozpuštěním $46,4 \mathrm{~g}$ dehydratované půdy v $950 \mathrm{ml}$ destilované vody a sterilací 20 minut při $121^{\circ} \mathrm{C}$. Do hotové a ochlazené $\left(45-50^{\circ} \mathrm{C}\right)$ půdy bylo před jejím nalitím na misky asepticky přidáno $50 \mathrm{ml}$ emulze vaječného žloutku (HiMedia) a rehydratovaný polymyxin $B$ sulfát (HiMedia, 50000 m.j.) tak, aby bylo dosaženo konečné koncentrace 100 jednotek polymyxin $B$ sulfátu na $\mathrm{ml}$ média. Hotová půda měla světlou sytě zelenou barvu.

g) Chromocult Coliform agar (Coli): byl připraven z dehydratované půdy dle návodu výrobce (Merck): rozpuštěním 26,5g dehydratované půdy v $1000 \mathrm{ml}$ destilované vody a sterilizací 20 minut při $121^{\circ} \mathrm{C}$. Hotová půda měla světlou lehce nažloutlou barvu.

h) Endo agar (Endo): byl připraven z dehydratované půdy dle návodu výrobce (Merck): rozpuštěním $39 \mathrm{~g}$ dehydratované půdy $v 1000 \mathrm{ml}$ destilované vody a sterilizací 20 minut při $121^{\circ} \mathrm{C}$. Hotová půda měla tmavě růžovou barvu.

i) MacConkey agar (Mac): byl připraven z dehydratované půdy dle návodu výrobce (Merck): rozpuštěním $50 \mathrm{~g}$ dehydratované půdy v $1000 \mathrm{ml}$ destilované vody a sterilizací 20 minut při $121^{\circ} \mathrm{C}$. Hotová půda měla světle růžovou barvu.

j) MRS agar (De Man, Rogosa and Sharpe agar) (MRS): byl připraven $z$ dehydratované půdy dle návodu výrobce (Merck): rozpuštěním $68,2 \mathrm{~g}$ dehydratované půdy $v 1000 \mathrm{ml}$ destilované vody a sterilizací 20 minut prí $121^{\circ} \mathrm{C}$. Do hotové a ochlazené $\left(45^{\circ} \mathrm{C}\right)$ pưdy byl před jejím nalitím na misky asepticky přidán aktidion $(0,025 \mathrm{~g}$ aktidionu $v 10 \mathrm{ml}$ destilované vody) a $\beta$-fenylethanol v konečné koncetraci $0,3 \%$ obj. Hotová půda měla žlutohnědou barvu.

\subsection{Mikroorganismy a kultivační podmínky}

Kmeny bakterií, které byly použity $v$ této práci, pocházejí z České sbírky mikroorganismů $(\mathrm{CCM}) \vee$ Brně. Seznam použitých kmenů a jejich označení je uveden $v$ tab. 1 . Kmeny byly uchovávány na šikmých masopeptonových (MPA) agarech pod parafinovým olejem a před vyočkováním na testované půdy byly inkubovány na MPA agaru při teplotě $28^{\circ} \mathrm{C}$ po dobu 48 hodin.

\subsection{Příprava bakteriální suspense a kultivační podmínky}

Suspense bakterií byly připraveny rozmícháním 1 kolonie ve sterilním fysiologickém roztoku, s výslednou koncentrací buněk přibližně 
Table 1 The list of strains and their designation

Tab. 1 Seznam kmenů a jejich označení

\begin{tabular}{|l|l|l|l|}
\hline Species / Druh & Strain / Kmen * & $\begin{array}{l}\text { Optimal growth temperature } \\
\text { / Optimální teplota růstu }\end{array}$ & Colony pigment / Pigment kolonií \\
\hline Bacillus cereus & $\mathrm{CCM} 2010^{\top}$ & $37^{\circ} \mathrm{C}$ & Whitish to cream / Bělavý až smetanově krémový \\
\hline Bacillus licheniformis & $\mathrm{CCM} 2145^{\top}$ & $50^{\circ} \mathrm{C}$ & $\begin{array}{l}\text { Whitish may become creamy or brown / Bělavý múže přejít } \\
\text { na krémový či hnědavý }\end{array}$ \\
\hline $\begin{array}{l}\text { Bacillus subtilis subsp. } \\
\text { subtilis }\end{array}$ & $\mathrm{CCM} 2216^{\top}$ & $30^{\circ} \mathrm{C}$ & $\begin{array}{l}\text { Whitish may become creamy or brown / Bělavý až } \\
\text { smetanově krémový }\end{array}$ \\
\hline Brevibacillus brevis & $\mathrm{CCM} 2050^{\top}$ & $30^{\circ} \mathrm{C}$ & Creamy to beige / Krémový až béžový \\
\hline Paenibacillus macerans & $\mathrm{CCM} 2012^{\top}$ & $37^{\circ} \mathrm{C}$ & Light creamy / Světle krémový \\
\hline
\end{tabular}

* CCM - Czech Collection of Microorganisms / Česká sbirka mikroorganismů, Brno, Czech Republic

\subsection{Preparation of bacterial suspensions and culture conditions}

Suspensions of bacteria were prepared by stirring one colony in sterile saline, with a final concentration of approximately $3 \times 10^{8}$ cells/ $\mathrm{ml}$. The suspension was diluted so as to give a separate and well visible colonies on Petri dishes. Incubation on tested media was conducted aerobically for 48 hours at $28^{\circ} \mathrm{C}$. After completion of cultivation, bacterial growth was evaluated and documented.

\section{RESULTS AND DISCUSSION}

The cultivation results are presented in Table 2. All strains were able to grow on the basic non-selective media (PCA, blood agar, MPA). The strains of $B$. cereus $\mathrm{CCM} 2010^{\top}$ and $B$. subtilis subsp. subtilis CCM $2216^{\top}$ grew faster on these culture media than other tested strains. After 18-24 hours, glossy, smooth colonies with irregular edges were visible on the plates (Fig. 1A). After an extension of the incubation time to 48 hours they significantly increased in size and changed their appearance to dry and wrinkled (Fig. 1B). The change in the appearance of the colonies occurred as a result of sporulation (Back, 2005).

Almost all strains grew on the selective media (MYP, PEMBA and TSB medium with the addition of polymyxin $B$ ). An exception was the strain P. macerans CCM $2012^{\top}$, which did not grow on TSB medium with the addition of polymyxin $B$, and its inability to hydrolyze casein was thus confirmed (Priest, 2015).

Thermophilic $B$. licheniformis CCM $2145^{\top}$ grew on culture media as fast as other (mesophilic) strains.

\subsection{Growth and appearance of colonies}

All strains grew on the basic non-selective cultivation media MPA, PCA and blood agar. It can be seen from Fig. 1, 2 and 3 that the morphology of bacillus colonies is highly variable. $B$. cereus grew in the form of large, convex, wrinkled colonies with irregular edges. On PCA and MPA agar the colonies had creamy-white pigment (Fig. 1B) and on blood agar brownish-green pigment (Fig. $3 A$ ). On all nonselective media, $B$. licheniformis formed medium-sized colonies, circular, flat and smooth (before sporulation) or slightly curved and
$3 \times 10^{8} / \mathrm{ml}$. Suspense byly naředěny tak, aby na Petriho miskách narostlo takové množství kolonií, aby byly jednotlivé kolonie oddělené a dobře viditelné. Kultivace na testovaných půdách probíhala aerobně při teplotě $28^{\circ} \mathrm{C}$ po dobu 48 hodin. Po ukončení kultivace byl růst bakterií vyhodnocen a zdokumentován.

\section{VÝSLEDKY A DISKUZE}

Výsledky kultivací jsou uvedeny $v$ tab. 2. Všechny kmeny byly schopné růst na základních neselektivních půdách (PCA, krevní agar, MPA). Kmeny $B$. cereus CCM $2010^{\top}$ a $B$. subtilis subsp. subtilis CCM $2216^{\top}$ vykazovaly na těchto půdách oproti zbylým testovaným kmenům rychlejší nárůsty. Po 18-24 hodinách byly na půdách viditelné lesklé, hladké kolonie s nepravidelnými okraji (obr. 1A). Po prodloužení inkubační doby na 48 hodin došlo $\mathrm{k}$ jejich výraznému zvětšení a ke změně vzhledu na suché a zvrásnělé (obr. 1B). Změna vzhledu kolonií nastala v důsledku sporulace (Back, 2005).

Na selektivních médiích (MYP, PEMBA a TSB médiu s prídavkem polymyxinu B) narostly téměř všechny kmeny. Výjimkou byl kmen $P$. macerans CCM $2012^{\top}$, který nevykazoval rùst na TSB médiu s prídavkem polymyxinu $\mathrm{B}$, tím byla potvrzena jeho neschopnost hydrolyzovat kasein (Priest, 2015).

Termofilní $B$. licheniformis $C C M 2145^{\top}$ rostl na kultivačních půdách stejně rychle jako ostatní (mesofilní) kmeny.

\subsection{Růst a vzhled kolonií}

Na základních neselektivních půdách, MPA, PCA a krevním agaru, rostly všechny bakteriální kmeny. Z obr. 1, 2 a 3 je patrné, že morfologie kolonií bacilů je značně variabilní. Bacillus cereus rostl ve formě velkých, vypouklých, zvrásněných kolonií s nepravidelnými okraji, které měly na PCA a MPA agarech smetanově bílou barvou (obr. 1B) a na krevním agaru hnědo-zelenou barvu (obr. 3A). B. licheniformis tvořil na MPA a PCA světle hnědé kolonie se smetanově bílým ohraničením (obr. $2 A)$. Na krevním agaru se tvořily kolonie bělavé barvy (obr. $3 B$ ). Na všech neselektivních půdách tvořil $B$. licheniformis kolonie středně velké, kulaté, ploché a hladké (před sporulací) či mírně vypouklé a zvrásněné s lesklým povrchem (po sporulaci). B. subtilis subsp. subtilis rostl na neselektivních půdách ve formě

Table 2 Growth of bacteria at $28^{\circ} \mathrm{C}$

Tab. 2 Růst bakterií při $28^{\circ} \mathrm{C}$

\begin{tabular}{|c|c|c|c|c|c|c|c|c|c|c|c|}
\hline \multirow{2}{*}{ Species / Druh } & \multirow{2}{*}{ Strain / Kmen } & \multicolumn{10}{|c|}{ Culture medium / Kultivační médium } \\
\hline & & MPA & PCA & TSB & KA & MYP & PEMBA & Coli & Endo & Mac & MRS \\
\hline Bacillus cereus & CCM 2010 & + & + & + & + & + & + & - & $+/-$ & - & - \\
\hline Bacillus licheniformis & CCM $2145^{\top}$ & + & + & + & + & + & + & - & - & - & - \\
\hline $\begin{array}{l}\text { Bacillus subtilis subsp. } \\
\text { subtilis }\end{array}$ & CCM $2216^{\top}$ & + & + & + & + & + & + & - & - & - & - \\
\hline Brevibacillus brevis & CCM $2050^{\top}$ & + & + & + & + & + & + & - & - & - & - \\
\hline Paenibacillus macerans & CCM $2012^{\top}$ & + & + & - & + & + & + & - & - & - & - \\
\hline
\end{tabular}

+ growth; - no growth; +/- little growth; MPA, nutrient agar; PCA, plate count agar; TSB, tryptone soya broth; KA, blood agar; MYP, phenol red egg yolk polymyxin agar; PEMBA, polymyxin pyruvate egg yolk mannitol bromothymol blue agar; Coli, chromocult coliform agar; Endo, Endo agar; Mac, MacConkey agar; MRS, De Man, Rogosa Sharpe agar

+ nárůst; - bez nárůstu; +/- malý nárůst; MPA, masopeptonový agar; PCA, plate count agar; TSB, tryptone soya bujón; KA, krevní agar; MYP, phenol red egg yolk polymyxin agar; PEMBA, polymyxin pyruvate egg yolk mannitol bromothymol blue agar; Coli, chromocult coliform agar; Endo, Endův agar; Mac, MacConkeyho agar; MSR, De Man, Rogosa Sharpe agar 

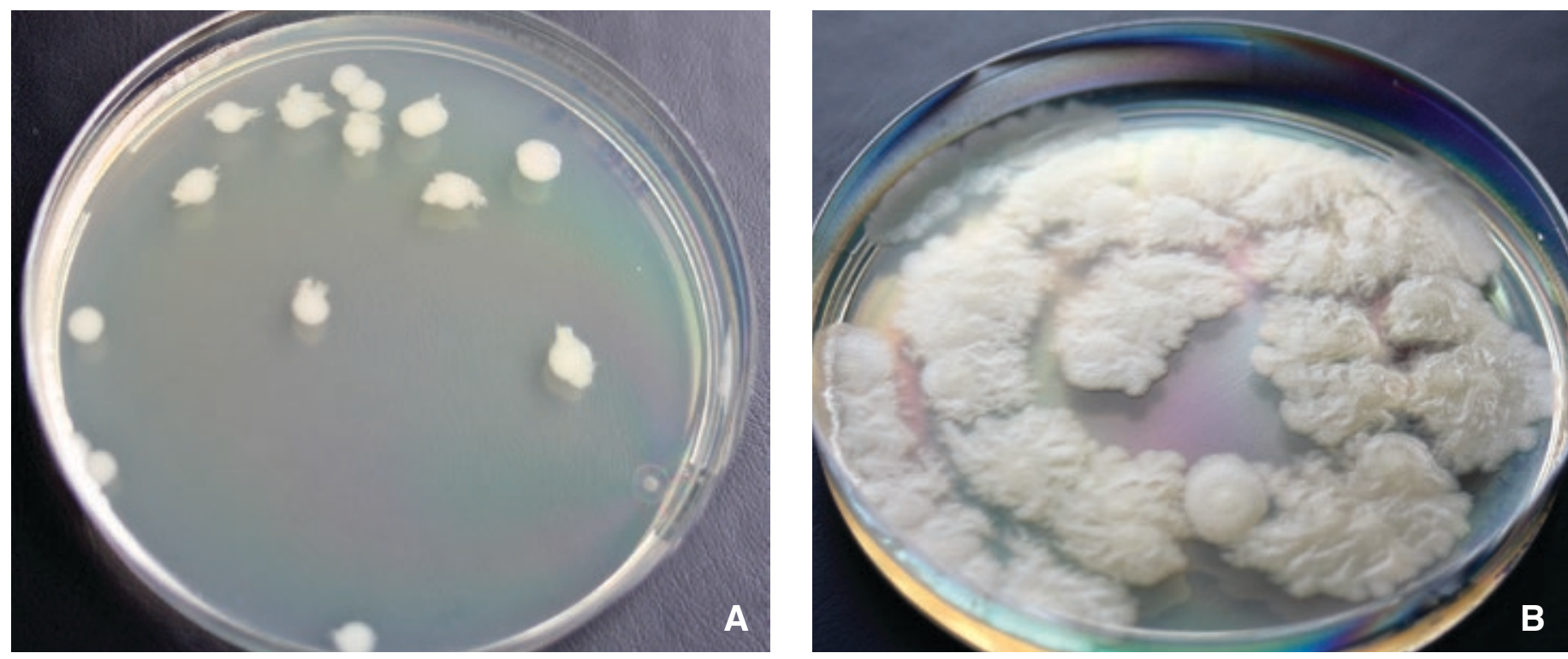

Fig. 1 Colonies of Bacillus cereus CCM $2010^{\top}$ on plate-count-agar at $28^{\circ} \mathrm{C}$; A, after 24 hours of incubation; B, after 48 hours of incubation Obr. 1 Kolonie Bacillus cereus $\mathrm{CCM} 2010^{\top}$ na plate-count agaru prii $28^{\circ} \mathrm{C}$; A, po 24 hodinách inkubace; B, po 48 hodinách inkubace
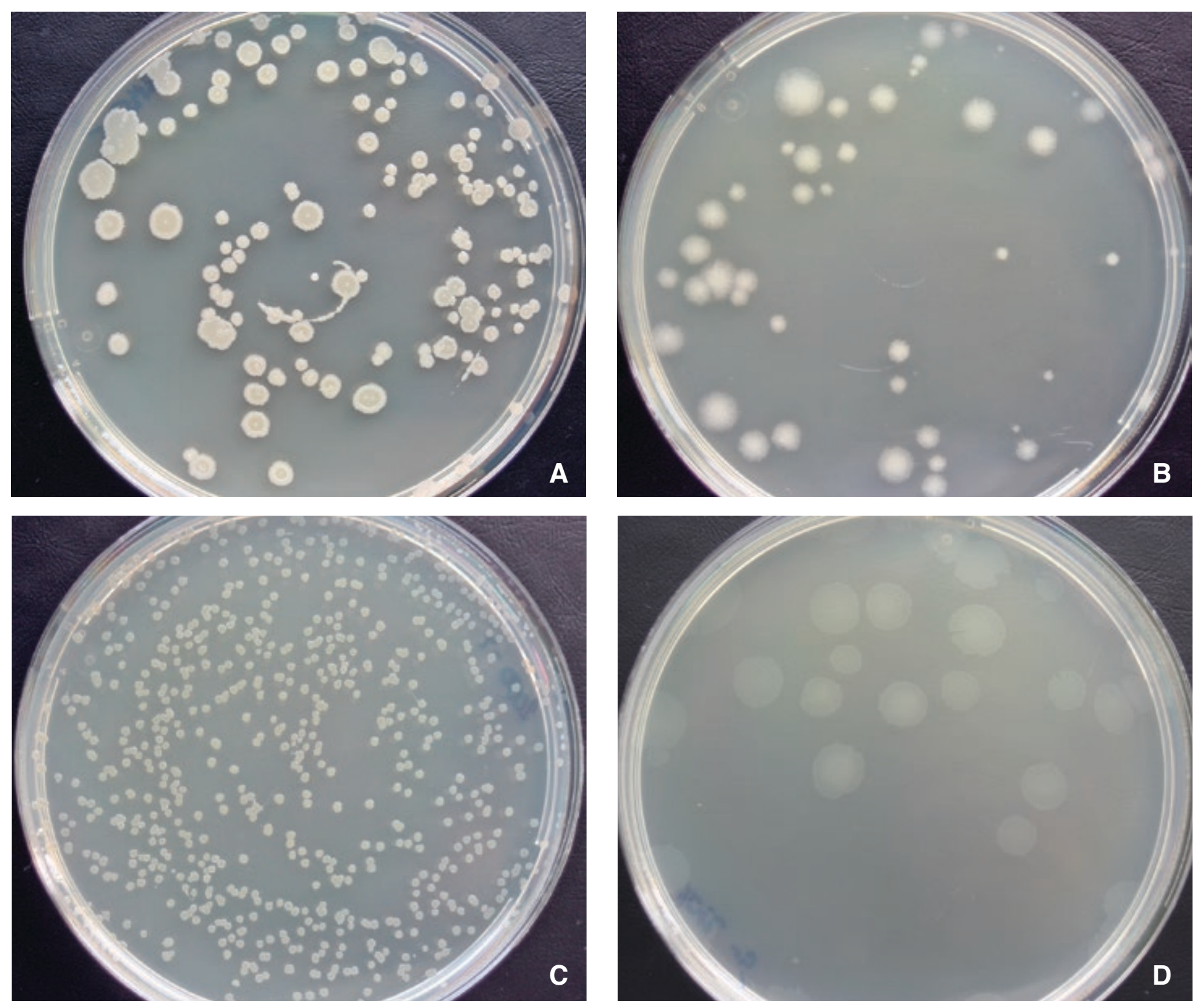

Fig. 2 Colonies of bacteria on nutrient agar after 48 hours of incubation at $28^{\circ} \mathrm{C}$

Obr. 2 Kolonie bakterií na masopeptonovém agaru po 48 hodinách inkubace při $28^{\circ} \mathrm{C}$;

A, Bacillus licheniformis CCM 2145'; B, Bacillus subtilis subsp. subtilis CCM 2216T; C, Brevibacillus brevis CCM 2050'; D, Paenibacillus macerans CCM $2012^{\top}$ 

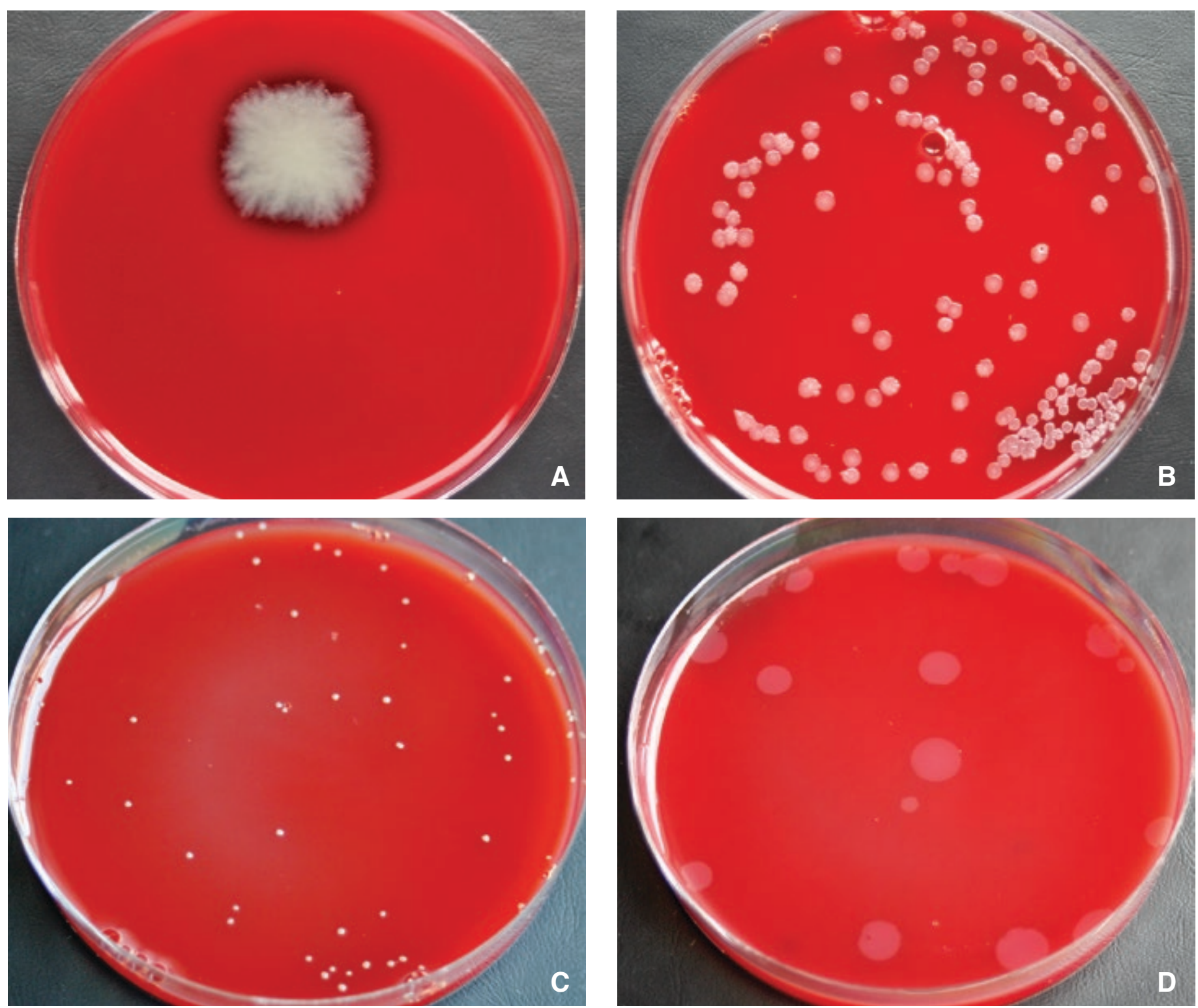

Fig. 3 Colonies of bacteria on blood agar after 48 hours of incubation at $28^{\circ} \mathrm{C}$ Obr. 3 Kolonie bakterií na krevním agaru po 48 hodinách inkubace při $28^{\circ} \mathrm{C}$

A, Bacillus cereus CCM 2010'; B, Bacillus licheniformis CCM 2145'; C, Brevibacillus brevis CCM 2050'; D, Paenibacillus macerans CCM $2012^{\top}$.
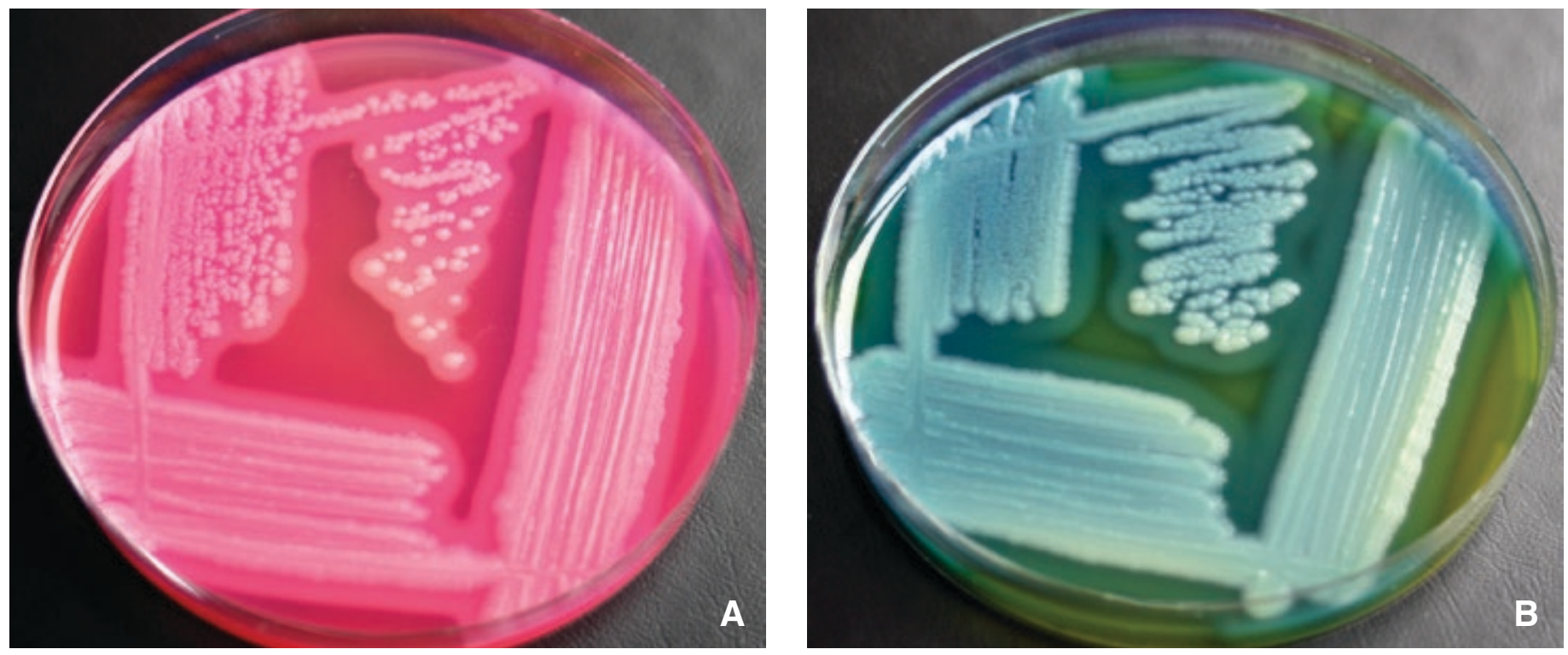

Fig. 4 Bacillus cereus CCM $2010^{\top}$ after 48 hours of incubation at $28^{\circ} \mathrm{C}$ Obr. 4. Bacillus cereus CCM $2010^{\top}$ po 48 hodinách inkubace při $28^{\circ} \mathrm{C}$ A, MYP agar; B, PEMB agar 
wrinkled with a glossy surface (after sporulation). B. subtilis subsp. subtilis grew on non-selective media in the form of medium-sized, circular, smooth and dry colonies with creamy white color and the structure of "icing sugar" (Fig. 2B). Like B. cereus, B. subtilis subsp. subtilis exhibited faster growth rate and the older colonies were significantly larger and had irregular edges. Brevibacillus brevis grew on PCA and MPA media in the form of regular, small, circular, flat, shiny colonies with creamy to beige pigment (Fig. 2C). In comparison with PCA and MPA media, smaller and white colonies were formed on blood agar (Fig. 3C). On these media, the colonies of $P$. macerans were circular, transparent with pale creamy pigment and regular edges (Fig. 2D and $3 D$ ). On the PCA medium, P. macerans formed smaller colonies than on blood agar and MPA.

All strains grew on selective MYP, PEMBA and TSB media with the addition of polymyxin $\mathrm{B}$ except $P$. macerans, which did not grow on TSB with the addition of polymyxin B. On MYP agar, $B$. cereus formed creamish-pink colonies (confirmation of its inability to utilize mannitol). These colonies were surrounded by an opalescent pink zone of precipitation (confirmation of lecithinase activity) (Fig. 4A). On solidified PEMBA medium, $B$. cereus formed creamish-blue colonies (inability to utilize mannitol), which were surrounded by the opalescent blue zone of precipitation (lecithinase activity) (Fig. 4B). In the case of PEMBA medium, the blue staining of $B$. cereus colonies was less intense and $B$. cereus could be misidentified (only on the basis of its lecithin activity). In this regard, MYP agar is a more suitable medium for the identification of $B$. cereus. The results were consistent with the descriptions of the colonies reported by Kramer and Gilbert (1989) and Němečková et al. (2011).

On MYP agar, the colonies of the strains $B$. licheniformis, $B$. brevis and $B$. subtilis subsp. subtilis (Fig. $5 A$ ) had creamy color without any visible zone of precipitation. $P$. Macerans created bright yellow colonies on this agar (Fig. 5B). On PEMB agar, colonies of the strains $B$. licheniformis and Brevibacillus brevis (Fig. 6A) had creamy to yellowish color. On this medium as well as on MYP agar, P. macerans formed bright yellow and mucoid colonies, which grew into the medium. The creamy and yellow color of the colonies confirmed the ability of the strains to utilize mannitol. On PEMBA medium, B. subtilis subsp. subtilis formed large whitish colonies that had a roughened surface at their center while the edges of the colonies were glossy and smooth (Fig. 6B).

None of the strains Bacillus, Brevibacillus and Paenibacillus grew on MRS medium, which is intended for the detection of lactic acid bacteria. Most of the strains did not grow on selective media, which are intended for the cultivation of gram-negative bacteria (Chromocult Coliform, Endo and MacConkey agar). An exception was the strain B. cereus CCM $2010^{\top}$, which grew slightly and formed a light pink colonies after 48 hours of cultivation on Endo agar (Fig. 7) (the středně velkých, kulatých, hladkých a suchých kolonií se smetanově bílým zabarvením a strukturou "moučkového cukru“ (obr. 2B). $B$. subtilis subsp. subtilis vykazoval, stejně jako $B$. cereus, rychlejši rychlost růstu a starší kolonie byly výrazně větší a měly nepravidelné okraje. B. brevis rostl na půdách PCA a MPA ve formě pravidelných, malých, kulatých, nevypouklých, lesklých kolonií krémové až béžové barvy (obr. $2 C$ ). Na krevním agaru tvořil v porovnání s PCA a MPA menší a bílé kolonie (obr. $3 C$ ). Kolonie $P$. macerans byly na těchto půdách kulaté, pravidelně ohraničené, transparentní a se světle krémovou barvou (obr. $2 D$ a $3 D$ ). Na půdě PCA tvořil v porovnání s krevním agarem a MPA $P$. macerans menší kolonie.

Na selektivních půdách MYP, PEMBA a TSB s príidavkem polymyxinu $B$ narostly všechny kmeny kromě $P$. macerans, který nerostl na TSB s př́lavkem polymyxinu B. Bacillus cereus tvořil na MYP agaru krémově-růžové kolonie (potvrzení neschopnosti utilisovat manitol), které byly obklopeny opalizující růžovou zónou precipitace (potvrzení lecitinasové aktivity) (obr. 4A). Na ztužené půdě PEMBA byly jeho kolonie zabarveny do krémově-modré barvy (neschopnost utilisovat manitol) a byly obklopeny opalizující modrou zónou precipitace (lecitinasová aktivita) (obr. $4 B$ ). U půdy PEMBA bylo modré zabarvení kolonií $B$. cereus méně intenzivní a mohlo by tak dojít $k$ jeho chybné identifikaci (pouze na základě jeho lecitinasové aktivity). $Z$ tohoto hlediska se jako vhodnější půda pro identifikaci $B$. cereus ukazuje MYP agar. Výsledky byly ve shodě s popisy kolonií uváděnými v publikacích Kramera a Gilberta (1989) a Němečkové et al. (2011).

Kolonie kmenů $B$. licheniformis, $B$. brevis a $B$. subtilis subsp. subtilis (obr. $5 A$ ) měly na půdě MYP krémové zabarvení a nebyla u nich viditelná zóna precipitace. $P$. macerans tvořil na této půdě jasně žluté kolonie (obr. $5 B)$. Na půdě PEMBA byly kolonie kmenů $B$. licheniformis a $B$. brevis (obr. $6 A$ ) krémové až žlutavé barvy. $P$. macerans tvořil na této půdě křiklavě žluté, slizovité, prorůstající kolonie stejně jako na MYP agaru. Krémová a žlutá barva kolonií potvrzovala schopnost daných kmenů utilisovat manitol. $B$. subtilis subsp. subtilis tvořil na této půdě velké bělavé kolonie, které měly ve svém středu zdrsnělý povrch, zatímco okraje kolonií byly lesklé a hladké (obr. $6 B)$.

Na půdě MRS, která je určena pro detekci mléčných bakterií, nenarostl žádný z kmenů rodů Bacillus, Brevibacillus a Paenibacillus. Většina kmenů nerostla na selektivních půdách pro kultivace gramnegativních bakterií (Chromocult Coliform, Endùv a MacConkeyho agar). Výjimkou byl kmen B. cereus CCM $2010^{\top}$, který po 48 hodinách kultivace slabě narostl na Endově agaru a vytvořil na něm světle růžové kolonie (obr. 7 ) (barva kolonií potvrdila, že $B$. cereus neutilisuje laktosu, což je ve shodě s Loganem a De Vosem (2015)). Slabý nárůst některých grampositivních bakterií na Endově agaru výrobce půdy nevylučuje.
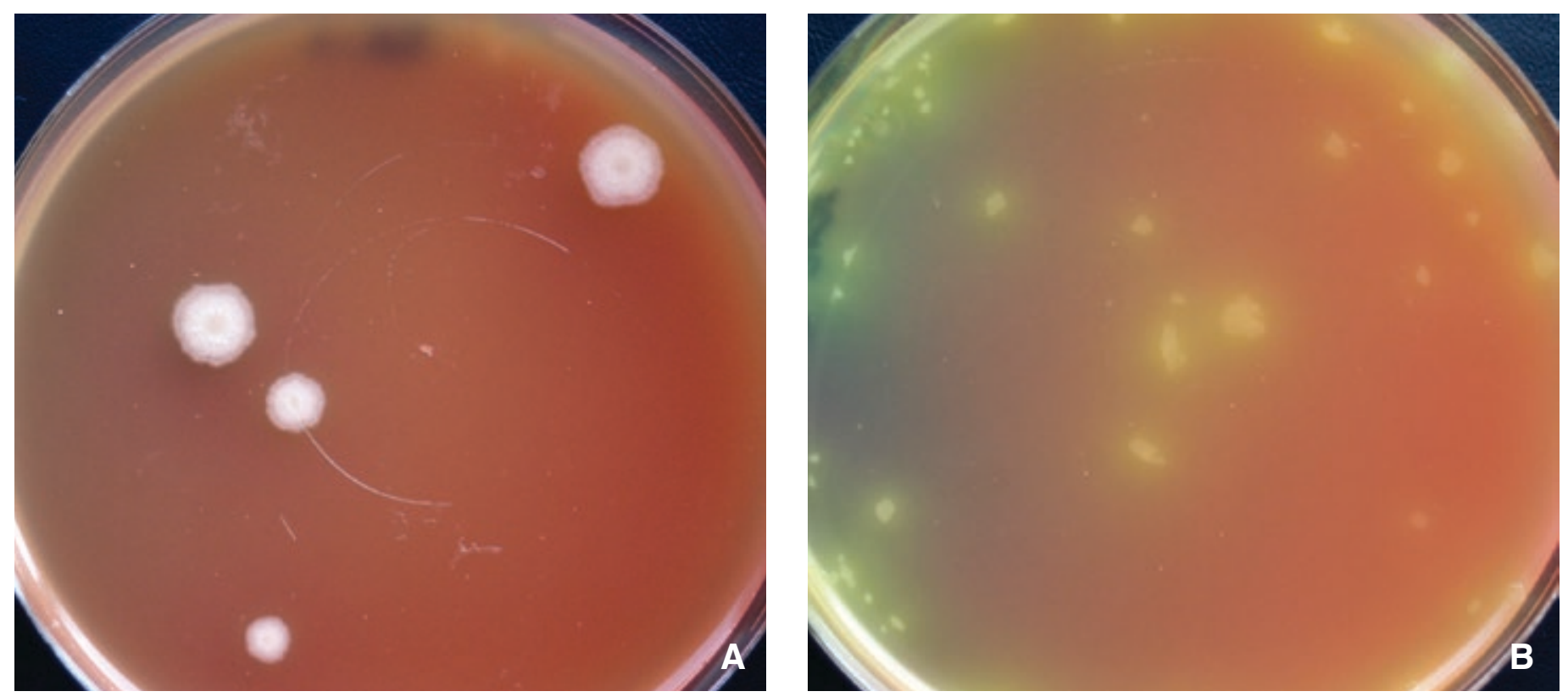

Fig. 5 Colonies of bacteria on Phenol Red Egg Yolk Polymyxin Agar after 48 hours of incubation at $28^{\circ} \mathrm{C}$

Obr. 5 Kolonie bakterií na MYP agaru po 48 hodinách inkubace prí $28^{\circ} \mathrm{C}$

A, Bacillus subtilis subsp. subtilis CCM $2216^{\top}$; B, Paenibacillus macerans CCM $2012^{\top}$. 

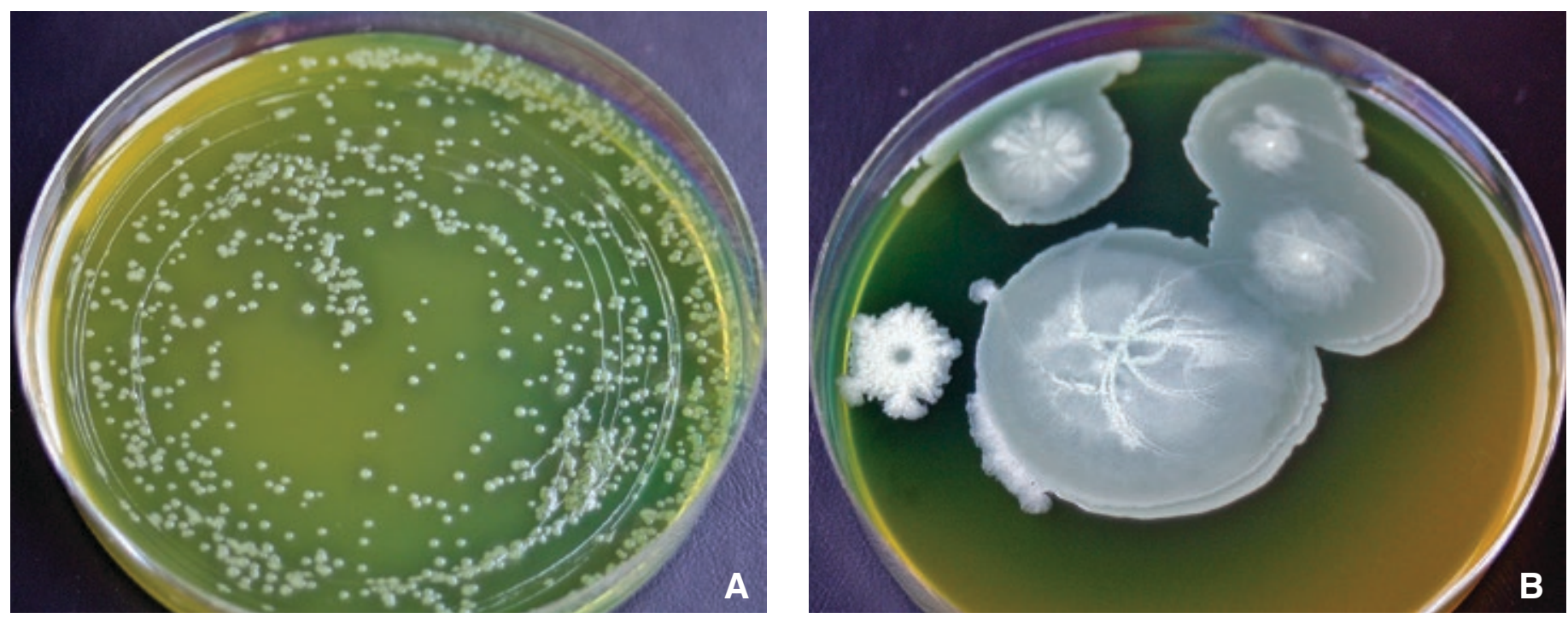

Fig. 6 Colonies of bacteria on Polymyxin Pyruvate Egg Yolk Mannitol Bromothymol Blue Agar after 48 hours of incubation at $28{ }^{\circ} \mathrm{C}$ Obr. 6 Kolonie bakterií na PEMB agaru po 48 hodinách inkubace při $28^{\circ} \mathrm{C}$

A, Brevibacillus brevis CCM $2050^{\top}$; B, Bacillus subtilis subsp. subtilis CCM $2216^{\top}$.

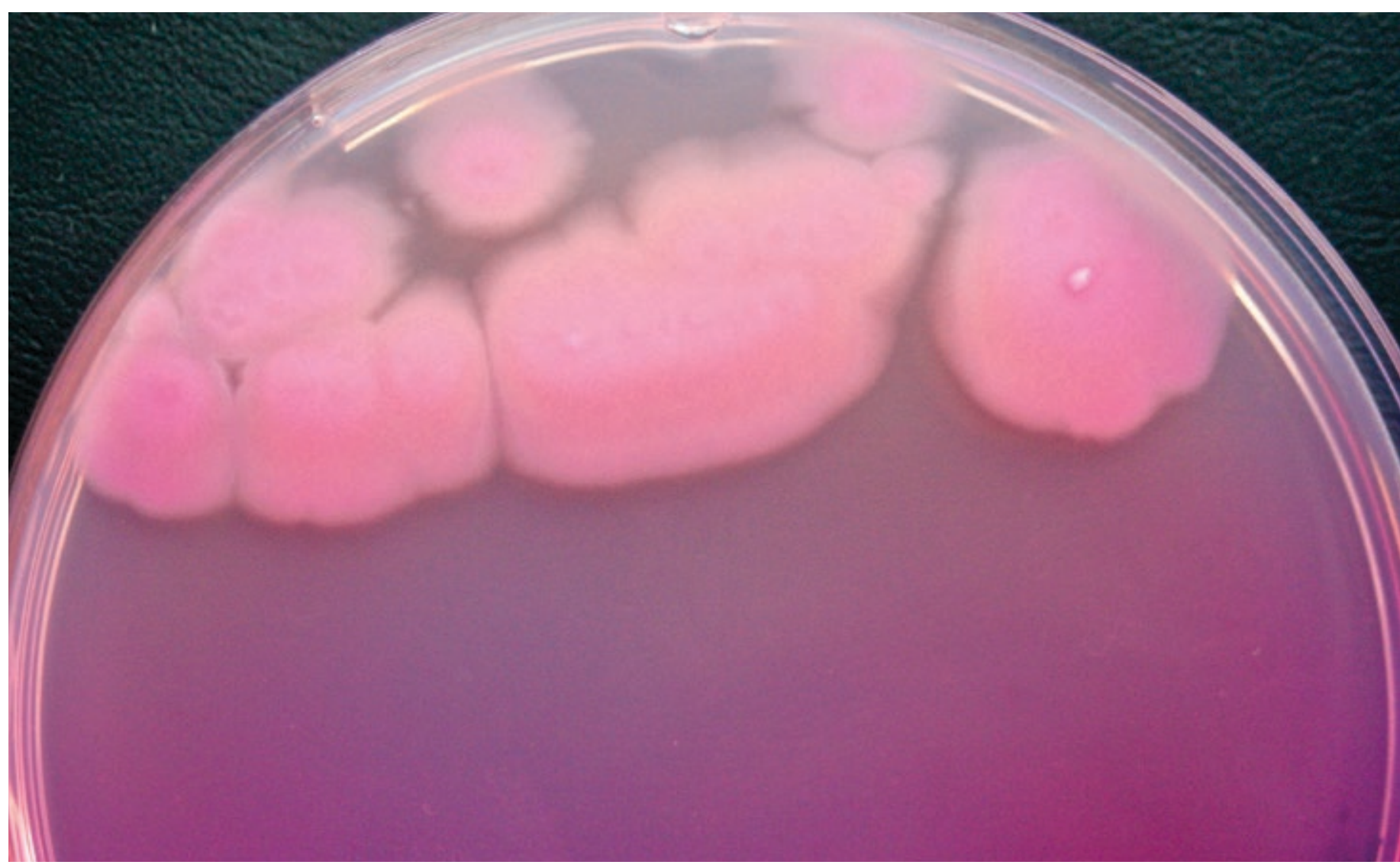

Fig. 7 Colonies of Bacillus cereus CCM $2010^{\top}$ on Endo agar after 48 hours of incubation at $28^{\circ} \mathrm{C}$ Obr. 7 Kolonie Bacillus cereus CCM $2010^{\top}$ na Endově agaru po 48 hodinách inkubace prì $28^{\circ} \mathrm{C}$.

color of the colonies confirmed that $B$. cereus does not utilize lactose, which is in agreement with Logan and De Vos (2015)). The media manufacturer does not exclude a slight growth of some grampositive bacteria on Endo agar.

\section{CONCLUSIONS}

The genus Bacillus is considered to be a low-risk contaminant of beer and its specific monitoring is not common. Bacillus vegetative cells are not able to grow and multiply in beer, but the spores of these microorganisms may survive in beer even for a long time. Another

\section{ZÁVĔR}

Rod Bacillus je v pivovarství považován za málo rizikovou kontaminantu a jako takový není běžně cíleně sledován. Vegetativní buňky Bacillus nejsou schopny růstu a množení v pivu, spory těchto mikroorganismů však mohou v pivu přežít i po dlouhou dobu. Dalším rizikovým faktorem je schopnost některých bacilů redukovat dusičnany na dusitany a podílet se na vzniku karcinogenních nitrosaminů. Zvýšené riziko by mohl představovat druh $B$. cereus, který je navíc schopen produkovat celou rradu toxinů.

Většina kmenů vykazovala rưst na selektivních médiích, určených primárně pro diagnostiku $B$. cereus (MYP, PEMBA, TSB s př́davkem 
risk factor is the ability of some bacilli to reduce nitrates to nitrites, thus contributing to the formation of carcinogenic nitrosamines. $B$. cereus may represent an increased risk due to its ability to produce various toxins.

Most strains showed growth on selective media, which are primarily intended for diagnostics of $B$. cereus (MYP, PEMBA and TSB with the addition of polymyxin $\mathrm{B}$ ). The exception was the strain $P$. macerans CCM $2012^{\top}$, which did not grow on TSB medium with the addition of polymyxin B. B. cereus CCM $2010^{\top}$ and B. subtilis subsp. subtilis CCM $2216^{\top}$ showed higher growth rates than other strains on all media. The most suitable medium for the isolation of bacilli was MYP agar, which gave the most significant color differentiation.

None of the strains showed growth on MRS agar. Most of the strains did not grow on selective media for the cultivation of gramnegative bacteria (Chromocult Coliform, Endo and MacConkey agar). An exception was the strain B. cereus $\mathrm{CCM} 2010^{\top}$, which grew slightly and formed a light pink colonies after 48 hours of cultivation on Endo agar. All strains of bacilli were able to grow on common and readily available culture media (nutrient agar, plate count agar, blood agar), which are used to determine the total number of microorganisms in food.

\section{ACKNOWLEDGEMENTS}

The results were obtained with the support of the Ministry of Education, Youth and Sports of the Czech Republic - Research Sensory Center in Prague and Research and Development Center - Sustainability and Development (LO1312).

\section{REFERENCES / LITERATURA}

Atlas, R.M., 2010: Handbook of microbiological media, 4th edition. CRC Press. ISBN: 978-1-4398-0406-3.

Back, W., 2005: Brewery. In: Back W. (Ed.), Colour atlas and handbook of beverage biology. Verlag Hans Carl, Nürnberg, Germany.

Basařová, G., Šavel, J., Basař, P., Lejsek, T., 2010: Pivovarství - Teorie a praxe výroby piva. Vydavatelství VŠCHT Praha.

Bokulich, N.A., Bamforth, C.W., 2013: The microbiology of malting and brewing. Microbiol. Mol. Biol. Rev., 77: 157-172.

Briggs, D.E., Boulton, C.A., Brookes, P.A., Stevens, R., 2004: Brewing science and practice. Woodhead Publishing Limited and CRC Press LLC. ISBN 1855734907.

Brožová, M., Kubizniaková, P., Matoulková, D., 2018: Brewing microbiology - bacteria of the genera Bacillus, Brevibacillus and Paenibacillus and cultivation methods for their detection - part I. Kvasny Prum., 64(2): 50-57.

Cladera-Olivera, F., Caron, G.R., Brandelli, A., 2004: Bacteriocin-like substance production by Bacillus licheniformis strain P40. Lett. Appl. Microbiol., 38: 251-256.

Drobniewski, F.A., 1993: Bacillus cereus and related species. Clin. Microbiol. Rev., 6: 324-338.

Edwards, S.G., Seddon, B., 2000: Selective medium based on tyrosine metabolism for the isolation and enumeration of Brevibacillus brevis (Bacillus brevis). Lett. Appl. Microbiol., 31(5): 395-399.

Harmon, S.M., Kautter, D.A., McClure, F.D., 1984: Comparison of selective plating media for enumeration of Bacillus cereus in foods. J.Food Prot., 47: 65-67.

Kramer, J.M., Gilbert, R.J., 1989: Foodborne bacterial pathogens. Michael Doyle. CRC Press. ISBN 0824778669. polymyxinu B). Výjimkou byl kmen Paenibacillus macerans CCM $2012^{\top}$, který nerostl na TSB médiu s prídavkem polymyxinu B. B. cereus CCM $2010^{\top}$ a $B$. subtilis subsp. subtilis CCM $2216^{\top}$ vykazovaly oproti ostatním kmenům na všech půdách vyšší rychlost růstu. Jako nejvhodnější půda pro stanovení bacilů se ukázal MYP agar, který poskytl nejvýraznější barevné odlišení.

Žádný z kmenů nevykazoval růst na MRS agaru. Většina kmenů nerostla na selektivních půdách pro kultivace gramnegativních bakterii (chromocult coliform, Endův a MacConkeyho agar). Výjimkou byl Bacillus cereus CCM $2010^{\top}$, který po 48 hodinách kultivace slabě narostl na Endově agaru a vytvořil na něm světle růžové kolonie. Všechny kmeny bacilů byly schopny růst na běžných a snadno dostupných kultivačních médiích (masopeptonový agar, plate count agar, krevní agar), které se používají na stanovení celkového počtu mikroorganismů v potravinách.

\section{PODĚKOVÁNÍ}

Výsledky byly získány s využitím podpory Ministerstva školství, mládeže a tělovýchovy ĆR - Výzkumné senzorické centrum v Praze a Výzkumná a vývojová varna - udržitelnost a rozvoj (LO1312).
Logan, N.A., De Vos, P., 2015a: Bacillus. In: Whitman, W.B., editor, Bergey's Manual of Systematics of Archaea and Bacteria. John Wiley \& Sons, Inc., in association with Bergey's Manual Trust.

Logan, N.A., De Vos, P., 2015: Bacillus In: Whitman, W.B., editor, Bergey's Manual of Systematics of Archaea and Bacteria. John Wiley \& Sons, Inc., in association with Bergey's Manual Trust.

Nehra, V., Saharan, B.S., Choudhary, M., 2016: Evaluation of Brevibacillus brevis as a potential plant growth promoting rhizobacteria for cotton (Gossypium hirstum) crop. Springerplus, 5(1): 948.

Němečková, I., Solichová, K., Roubal, P., Uhrová, B., Šviráková, E., 2011: Methods for detection of Bacillus sp., B. cereus, and B. licheniformis in raw milk. Czech J. Food Sci., 29: 55-60.

Priest, F.G., 2015: Paenibacillus. In: Whitman, W.B., editor, Bergey's Manual of Systematics of Archaea and Bacteria. John Wiley \& Sons, Inc., in association with Bergey's Manual Trust.

Salkinoja-Salonen, M.S., Vuorio, R., Andersson, M.A., Kämpfer, P., Andersson, M.C., Honkanen-Buzalski, T., Scoging, A.C., 1999: Toxigenic strains of Bacillus licheniformis related to food poisoning. Appl. Environ. Microbiol., 65(10): 4637-4645.

Te Giffel, M., Beumer, R., Hoekstra, J., Rombout, F.M. 1995: Germination of bacterial spores during sample preparation. Food. Microbiol., 12: 327-332.

Vaughan, A., O'Sullivan, T., van Sinderen, D., 2005: Enhancing the microbiological stability of malt and beer-a review. J. Inst. Brew., 111: 355-371.

Manuscript received / Do redakce došlo: 04/07/2018 Accepted for publication / Prijato k publikování: 07/08/2018 